\title{
Structural and physical-functional deficits in lower limbs with fractures and treated surgically
}

\author{
Déficits estruturais e físico-funcionais do membro \\ inferior com fratura e tratado cirurgicamente
}

Déficits estructurales y físico-funcionales del miembro inferior con fractura tratado quirúrgicamente

\author{
Micaele Aparecida Furlan de Oliveira ${ }^{[\mathrm{a}]}$, Osmair Gomes de Macedo ${ }^{[\mathrm{a}]}$, \\ Lilian Carolina Rodrigues da Silva ${ }^{[\mathrm{a}]}$, Thaís Santos Oliveira ${ }^{[\mathrm{a}]}$, Martim Bottaro ${ }^{[\mathrm{b}]}$, \\ Wagner Rodrigues Martins ${ }^{[]^{*}}$
}

[a] Faculdade de Ceilândia, Universidade de Brasília (UnB), Brasília, DF, Brazil

[b] Faculdade de Educação Física, Universidade de Brasília (UnB), Brasília, DF, Brazil

\begin{abstract}
Introduction: A fracture is a traumatic bone injury that can occur from a variety of causes. Although the repercussions of fractures on the musculoskeletal system are documented, studies with more comprehensive outcomes and later stages of injury are still scarce. Objective: To evaluate the structural and physicalfunctional adaptations in individuals who suffered unilateral lower limb fractures treated surgically. Methods: Thirty-two patients of both genders, aged between 18 and 59 years, with a diagnosis of unilateral
\end{abstract}

\footnotetext{
*MAFO: MS, e-mail: micaele-furlan@hotmail.com OGM: PhD, e-mail: osmair@unb.br LCRS: Undergrad, e-mail: lilianroodrigues@gmail.com TSO: Undergrad, e-mail: thaissantos.thatha@gmail.com MB: PhD, e-mail: martim.bottaro@gmail.com WRM: PhD, e-mail: professorwagnermartins@gmail.com
} 
fracture of the lower limb and hospital discharge of at least one year, participated in the study. The affected lower limb was compared to the healthy lower limb of all participants using the outcome measures: vastus lateral muscle thickness (ultrasonography), knee extension and flexion strength (isokinetic dynamometer), ankle dorsiflexion range of motion of the distance from the foot to the wall) and functional fitness of the lower limb (single and triple horizontal jump test). Results: Statistically significant differences were found between the limbs affected and not affected in the measurements of muscle thickness ( $p=0.0001)$, knee extension force $(p=0.0094)$, dorsiflexion amplitude $(p=0.0004)$ and functional performance $(p=0.0094$, single jump and $=0.0114$, triple jump). In all significant outcomes, the values of the affected limb were smaller than that of the non-affected limb. The peak torque of the knee flexor muscles did not show a statistically significant difference between limbs $(p=0.0624)$. Conclusion: Individuals who have undergone a surgically treated unilateral fracture of the lower limb present important structural and physical-functional late changes in relation to the non-affected limb.

Keywords: Bone Fractures. Musculoskeletal System. Muscle Weakness. Range of Joint Motion.

\section{Resumo}

Introdução: Fratura é uma lesão traumática sofrida pelo osso que pode ocorrer por causas diversas. Embora as repercussões das fraturas sobre o sistema musculoesquelético sejam documentadas, estudos com medidas desfecho mais abrangentes e em fases mais tardias da lesão ainda são escassos. Objetivo: Avaliar as adaptações estruturais e físico-funcionais em indivíduos que sofreram fratura unilateral de membro inferior tratadas cirurgicamente. Métodos: Participaram do estudo 32 pacientes de ambos os sexos, com idade entre 18 e 59 anos, com diagnóstico de fratura unilateral de membro inferior e alta hospitalar de no mínimo 1 ano. $O$ membro inferior acometido foi comparado ao membro inferior saudável de todos os participantes utilizando as medidas de desfecho: espessura muscular do vasto lateral (ultrassonografia), força de extensão e flexão do joelho (dinamômetro isocinético), amplitude de movimento de dorsiflexão do tornozelo (teste da distância do pé à parede) e aptidão funcional do membro inferior (teste de salto horizontal simples e triplo). Resultados: Foram encontradas diferenças estatisticamente significativas entre os membros acometidos e não acometidos nas medidas de espessura muscular $(p=0,0001)$, força de extensão do joelho $(p=0,0094)$, amplitude de dorsiflexão ( $p=0,0004)$ e desempenho funcional ( $p=0,0094$, salto simples e $p=0,0114$, salto triplo). Em todos os desfechos significativos os valores do membro acometido foram menores que o do membro não acometido. 0 pico de torque dos músculos flexores do joelho não demonstrou diferença estatisticamente significante entre membros ( $p=0,0624)$. Conclusão: Indivíduos que sofreram fratura unilateral de membro inferior tratado cirurgicamente apresentam alterações estruturais e físico-funcionais tardias importantes em relação ao membro não acometido.

Palavras-chave: Fraturas Ósseas. Sistema Musculoesquelético. Debilidade Muscular. Amplitude de Movimento Articular.

\section{Resumen}

Introducción: La fractura es una lesión traumática sufrida en el hueso que puede ocurrir por diversas causas. Aunque las repercusiones de las fracturas en el sistema músculoesquelético estén documentadas, aún son escasos los estudios con un desenlace más amplio y en fases tardias de la lesión. Objetivo: Evaluar las adaptaciones estructurales y físico-funcionales en individuos que sufrieron fractura unilateral del miembro inferior tratados quirúrgicamente. Métodos: Participaron del estudio 32 pacientes de ambos sexos, con edad entre 18 y 59 años, diagnosticados con fractura unilateral del miembro inferior y alta hospitalar de por lo menos un año. El miembro inferior dañado fue comparado al miembro inferior saludable de todos los participantes utilizando las siguientes 
medidas: espesura muscular del vasto lateral (ultrassonografia), fuerza de extensión y flexión de la rodilla (dinamómetro isocinético), amplitud de movimiento de dorsiflexión del tobillo (test de la distancia del pie a la pared) y aptitud funcional del miembro inferior (test de salto horizontal simple y triple). Resultados: Fueron encontradas diferencias estadísticamente significativas entre los miembros dañados y los sanos en las medidas de espesura muscular ( $p=0,0001)$, fuerza de extensión de la rodilla $(p=0,0094)$, amplitud de dorsiflexión $(p=0,0004)$ $y$ desempeño funcional ( $p=0,0094$, salto simple y $p=0,0114$, salto triple). En todas las conclusiones significativas los valores del miembro dañado fueron menores que en las del miembro sano. El pico de torsión de los músculos flexores de la rodilla no demostró diferencia estadísticamente significativa entre ambos miembros $(p=0,0624)$. Conclusión: los individuos que sufrieron fractura unilateral del miembro inferior tratado quirúrgicamente presentan alteraciones estructurales y físico-funcionales importantes en relación con el miembro sano.

Palabras clave: Fracturas Óseas. Sistema Musculoesquelético. Debilidad Muscular. Rango del Movimento Articular.

\section{Introduction}

Fracture is a bone injury caused by a high magnitude of tensile, shear, compression or twist loads, resulting in loss of bone capacity in transmitting load during movement [1]. The injury can occur by an automobile accident, falls, work accidents, trauma in the sport, injuries by weapon, firearm projectile injury, fall on a pointed object, among others. Depending on the type and magnitude of the force exerted at the moment of the injury, the fracture presents itself in varied forms and with different segments affected [2]. Regarding body location, studies point to a higher incidence of fractures in the lower limbs than in the upper limbs [3 - 5], with the tibia being the most common site, followed by the femur, foot and patella [6 - 8]. Although fractures in the lower limbs are not responsible for fatal causes, they can cause incapacity to work and decrease the quality of life of the individual $[9,10]$. Regarding gender, there is a predominance of fractures in young male adults and in women, the highest incidence occurs after menopause [11 - 13].

The studies of Naumann et al. [14] and Albuquerque et al. [4] estimated that in the United States alone, in fatal and nonfatal automobile injuries, costs measured with hospitalization, treatment, rehabilitation services, and reduced productivity or long-term disability exceed $\$ 99$ billion per year. Regarding the physical consequences, the survivor of a motorcycle accident, for example, can take, on average, one to six months to fully recover [15]. In more complex lesions, patients undergoing surgical procedures can get up to 18 months to recover from surgery, fracture and resume their activities of daily living [16].
After a fracture of the lower extremity, the period of immobility of the affected limb and the time of hospitalization of these patients may be factors capable of negatively influencing the body composition and the physical-functional aspects of the patients. Due to the need for postoperative medical follow-up and long periods of bed restriction in the hospital phase, it can cause muscular and bone hypotrophy, ligament and capsular retraction, joint stiffness and circulatory changes $[17,18]$. Even after years of hospital discharge, the patient may present negative physical-functional consequences, since there may be a delay in joining a rehabilitation program due to the difficulty of access to the public health system or the lack of effectiveness of the treatment $[19,20]$.

Much has been investigated on the quality of life and reported functional disability of patients who have suffered from lower extremity fracture. In the study by Sanders et al. [21], patients aged 18 to 65 years who required surgical treatment were followed up by means of measurements using instruments that evaluate pain, stiffness and function of the lower limb. The results showed that musculoskeletal recovery occurred significantly in the first 6 months and that residual functional deficits were still observed 12 months after injury. In the study by Son et al. [22] performed with patients who suffered unilateral fractures of the lower limb (age between 18 and 100 years), patients were shown to be physically and psychologically incapacitated after six months of injury (World Health Organization Quality of Life Assessment [WHOQOL]) bone. The study by Stevens et al. [23] performed with individuals aged between 19 and 62 years, observed a decrease in the muscular mass of the dorsiflexors and 
plantar flexors in the first two weeks of immobilization of the fractured lower limb. The muscle strength deficit between affected and non-affected limbs in elderly patients, in a period of six months to seven years after discharge from a femoral fracture, has also been documented [24]. The decrease in muscle mass was also demonstrated in a population of 357 patients aged 55 years or more after hip fracture, and this decrease was associated with physical disabilities, mobility limitation, falls and subsequent loss of independence [25]. Faergemann et al. [26] in their study with 158 patients aged 18-64 years, demonstrated that in distal fractures of lower limbs great losses of range of motion and muscular strength occur. Leppalla et al. [27], when analyzing patients who suffered fractures of lower limbs in younger phases (age between seven and 15 years) demonstrated that the bone density and muscular strength of these patients are also significantly lower in the affected limb compared to the affected limb even after two years of injury.

Despite the available evidence, further studies are needed to more comprehensively and later observe deficits of the fractured lower limb and were treated surgically. Considering the need to describe the late deficits due to bone trauma, the objective of this study was to evaluate the structural and physical-functional alterations of the lower limbs after hospital discharge in individuals who suffered surgically treated unilaterally fracture of the lower limb.

\section{Methods}

This is a cross-sectional descriptive study. The research project of this study was submitted and approved by the Ethics Committee on Researches with Human Beings of the Faculty of Health Sciences of the University. All participants were informed about the risks and benefits of the study. Their participation occurred voluntarily through the signing of the Free and Informed Consent Term.

\section{Participants}

Patients who received care in the orthopedic ward of three hospitals of the Health Department of the Federal District were recruited. Participants were selected by convenience, sampling from a list of patients who were hospitalized in a post-operative situation in 2015 and 2016. As eligibility criteria, patients were recruited on hospital discharge from one year, age between 18 and 59 years, of both sexes, with diagnosis of a closed or exposed fracture of the femur, tibia or fibula submitted to surgical treatment. At the time of recruitment, individuals who used walking aids, had wounds and / or skin infection, bilateral lower limb fracture, previous fracture in the same bone, operative complications (osteomyelitis, deep vein thrombosis, heterotrophic ossification), pseudoarthrosis, joint contracture and motor sensory deficit due to peripheral nerve damage were excluded. Patients who suffered a fracture whose treatment was the arthroplasty were also excluded.

The total number of individuals in the list of three hospitals was 598 subjects. The application of the criteria for selection of the participants was done initially using the variables included in the list itself, in which it was possible to know, for example, the location of the fracture, the type of osteosynthesis used in the postoperative period and the age of the patients. After the initial exclusions, the patients who partially presented the selection criteria were contacted by telephone call, at which point the contact and the research objective were explained. Subjects with telephone contacts that did not exist or were unavailable after four attempts were excluded from the list. The flowchart of the recruitment step can be seen in Figure 1.

Figure $\mathbf{1}$ - Flowchart of the research steps.

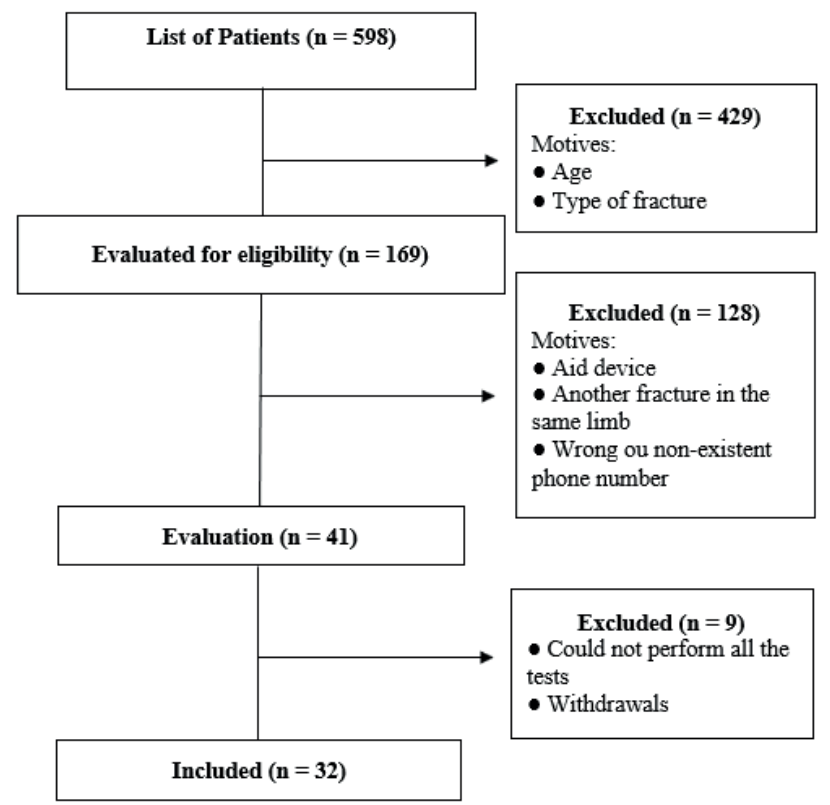


Sample characterization

Initially, an evaluation was carried out with the individual selected to participate in the study by means of an evaluation form elaborated by the authors. This evaluation recorded information such as age, gender, weight, height, BMI, occupation, bone trauma mechanism, type of fracture, length of hospital stay, physical therapy, among other inclusion criteria.

The Western Ontario \& McMaster Universities (WOMAC) questionnaire, which has translation and validation in the Portuguese language [28] and excellent intraclass correlation coefficient, was used to measure pain, rigidity and difficulty in performing tasks during the last 72 hours. (ICC $=0.964$ ) and internal consistency (Cronbach's $\alpha=0.917$ ) $[29,30]$. The WOMAC questionnaire contains 24 items in three dimensions: pain, stiffness and function. Your pain scale includes five items about the amount of pain in the various day-to-day activities while your stiffness scale has two items on joint stiffness upon waking and later in the day. The function scale asks about the degree of difficulty in doing 17 activities. All three response formats use "none" (or "no pain / stiffness / difficulty") and "extreme" outcomes with total scores ranging from zero (poor) to 96 (excellent) points [28].

In addition, the Lower Extremity Functional Scale (LEFS) was used to characterize the sample, which already presented Cronbach's $\alpha=0.952$ and the ICC $=0.957$ [31]. The questions are asked to easily assess the functional status of patients with musculoskeletal dysfunction affecting the lower extremities. In the questionnaire there are five categories of possible numerical answers, ranging from zero to four for each of your 20 questions, for a total score ranging from zero (bad) to 80 (excellent) points [31]. Although these two scales possess their psychometric properties studied, they do not have a cut-off point that dichotomously classifies the disability as present or absent.

\section{Outcome measures}

\section{Muscle thickness of the vastus lateralis}

The evaluation of muscular thickness was obtained by means of images taken by the B-mode scans (PhilipsVMI, Ultra Vision Flip, Model BF), together with the aid of a linear transducer of $70 \mathrm{~mm}$ and frequency of $7.5 \mathrm{MHz}$. The images were analyzed by the ImageJ application (National Institute of Health, USA, version 1.42). Previous studies have demonstrated that ultrasound showed high reliability and validity for assessing muscle thickness [32 - 36]. The images were acquired by a single previously trained examiner (training lasted $2 \mathrm{~h} 30 \mathrm{~m}$ ). During the examination the volunteer remained in supine position, with the body relaxed and with the lower limbs extended. The distance between the greater trochanter of the femur and the knee joint was identified, then the region was marked $50 \%$ of this length with the use of a metric tape laterally to the thigh [37 - 39]. In order to obtain the vastus lateralis images, the transducer was positioned longitudinally on the surface of the limb to be measured and a conductivity gel (Conductor Gel, Mercur Indústria e Comércio Ltda.) was used to promote better acoustic contact without the need to put pressure on the surface of the skin. Muscle thickness (MT) was the parallel distance between superficial aponeurosis (SA) and deep muscle aponeurosis [39 - 41]. Three MT photos of each member were recorded and for future calculation the physician for statistical analysis.

\section{Amplitude of dorsiflexion of the ankle}

For the assessment of ankle dorsiflexion, we followed the protocol of the study by Bennel et al [42] which suggest the functional measurement in a closed kinetic chain. Measurement occurs indirectly by means of a tape measure attached to the floor next to a wall. It is a simple and reliable method that has been shown to have high reliability in comparison with the goniometry test $[42,43]$. During the measurement the volunteer was positioned in orthostatism, with the foot to be evaluated on a tape measure that was fixed to the ground, straight, from a wall. The hallux remained on the tape, while the bent knee leaned against the wall. The volunteer was instructed to perform the dorsiflexion movement in a closed kinetic chain, sliding the foot in the posterior direction, as far as possible without removing the knee from the wall and the heel from the floor. When the maximum dorsiflexion was reached by the volunteer, the examiner read the distance between the hallux and the wall. Only one measurement was performed on each member for statistical analysis.

\section{Functional performance of the lower limb}

To evaluate the functional performance of the lower limbs the single and triple jumps were used. The simple unipodal jump test for distance is a functional measure commonly used to assess muscle strength, neuromuscular coordination, power and stability of the injured limb $[44,45]$. In the study by Bolga and Keskula [46], the simple jump test demonstrated excellent reliability, presenting an ICC of 0.96 and the 
standard error of measurement of $4.56 \mathrm{~cm}$. Like other jump tests, the triple unipodal jump for distance also presents advantages by having easy application, low cost and good validation and reliability. It is a test that requires a high demand of joint torque and a good development of muscle strength $[46,47]$. The reliability of the jump protocol used in the present study showed good reliability in previous studies (ICC $=0.98$, standard error of measurement $=16.1)[44,46]$.

For the simple horizontal jump, a tape measure was fixed to the ground perpendicular to a starting line. The volunteer was guided on the procedure of the jump and asked to remain in unipodal support and hands on the waist to avoid the push with the upper limbs. From the verbal command of "Prepare!", “Go!", the volunteer was instructed to jump as far as possible, starting from the starting point and remaining on the lower limb evaluated for marking. The maximum distance of the jump was recorded in centimeters and the test was performed three times with each limb and a final mean was performed for statistical analysis $[45,48]$. For the accomplishment of the triple horizontal jump, the same tape measure fixed to the ground for the simple jump was used. The volunteer was instructed to remain in unipodal support and hands at the waist to avoid push with the upper limbs. He was asked to jump as far as possible by means of three jumps, which must occur continuously, and the contralateral limb could not touch the ground. From the verbal command of "Prepare!", "Go!", the volunteer was instructed to jump and at the end should be kept on the lower limb evaluated for marking. The maximum distance of the three jumps was recorded in centimeters and the test was performed three times with each limb and a final mean for analysis $[45,47,48]$.

\section{Assessment of knee strength}

To evaluate the strength of the lower limb, we used an isokinetic dynamometer Biodex System 3 (Biodex Medical Inc., Shirley, NY) that provide us with objective measures of human muscle function in variables related to torque, power and muscular endurance [49]. The reliability of the isokinetic measurements is superior compared to other dynamometers, due to the decrease in human / physiological error in the influence of the variability of the measurements due to the constant velocity during the measurements $[50,51]$.

The isokinetic muscle strength of the lower limb was measured by the peak torque during the knee extension and flexion (concentric-concentric) movement at a velocity of $60^{\circ} / \mathrm{s}$. The member who initiated the evaluation was defined by lottery. The protocol was performed as follows: (a) Participant familiarization with six repetitions of concentric-concentric contraction of flexion and knee extension at $120^{\circ}$ / s; (b) yet to familiarize six repetitions at 90 / s; (c) main protocol, dependent variable, a series of four replicates at $60^{\circ}$ / $s$. The intervals between the series were one minute. The evaluation was carried out bilaterally.

To stabilize the body to the maximum and to minimize extra movements, the volunteers were placed in the chair of the dynamometer in a comfortable position and fastened to safety belts in the trunk, pelvis and thigh. The lateral epicondyle of the femur was considered the bone reference to align the axis of rotation of the knee and the axis of rotation of the device. The positioning of the subject in the chair allowed a free and comfortable movement of knee flexion and extension, and an amplitude of movement (ADM) of $80^{\circ}$ was standardized from the terminal flexion. After the positioning of the volunteer for the test, were adjusted: (a) chair height; (b) adjustment of the backrest; (c) position of the chair; (d) position of the dynamometer; (e) adjustment of the resistance arm. During the test, all the volunteers kept their arms crossed at the height of the thorax, holding the straps at the shoulders. Verbal encouragement and visual feedback were used by the Biodex monitor to attempt to achieve maximum effort level.

\section{Statistical analysis}

For characterization of the sample (epidemiological, medical and clinical data), descriptive statistics were used using absolute and percentage frequency values. Regarding the outcome measures, for the presented results, inferential statistics were used after verifying the normality of the data. The Shapiro Wilk test was used to test the normality of the data. Attested to normality, the data were analyzed with Student's t-test for independent samples for each outcome measure. The data were analyzed using the GraphPad Prism program. A significance level of $\mathrm{p} \leq 0.05$ was adopted for all variables. Effect size (difference between limbs) was calculated using the Cohen coefficient $\mathrm{d}$, according to the formula: effect (d) = mean of the affected limb - mean of the uninjured limb / pooled SD. An effect size $>0.8$ is considered broad, between $>0.2$ and $<0.8$ moderate and less than 0.2 small [52]. 


\section{Results}

In the sample studied, there was a higher incidence of males (71.9\%) and those aged $35-39$ years (25\%). The most frequent causes of fractures were motorcycle accidents (37.5\%) followed by falls (21.8\%), with tibial and fibular fractures being more frequent $(25 \%)$. The prevalence of the fractured limb was $53.1 \%$ for the left limb, and $93.7 \%$ of the patients had the right limb as the dominant limb. Seventy-five percent of the patients presented injury time over three years. The other sample characterization data are presented in Table 1.

Table 1 - Characterization data of the sample

\begin{tabular}{|c|c|c|}
\hline Variable & Frequency & Percentage \\
\hline \multicolumn{3}{|l|}{ Sociodemographic variables } \\
\hline \multicolumn{3}{|l|}{ Sex } \\
\hline Male & 23 & $71.9 \%$ \\
\hline Female & 9 & $28.1 \%$ \\
\hline \multicolumn{3}{|l|}{ Age (years) } \\
\hline 15 to 19 & 1 & $3.1 \%$ \\
\hline 20 to 24 & 1 & $3.1 \%$ \\
\hline 25 to 29 & 7 & $21.8 \%$ \\
\hline 30 to 34 & 3 & $9.3 \%$ \\
\hline 35 to 39 & 8 & $25 \%$ \\
\hline 40 to 44 & 2 & $6.3 \%$ \\
\hline 45 to 49 & 5 & $15.7 \%$ \\
\hline 50 to 54 & 3 & $9.4 \%$ \\
\hline 55 to 59 & 2 & $6.3 \%$ \\
\hline \multicolumn{3}{|l|}{ BMI } \\
\hline < 18,5 (Low weight) & 1 & $3.1 \%$ \\
\hline$\geq 18,5 \mathrm{e}<25$ (Adequate weight) & 10 & $31.2 \%$ \\
\hline$\geq 25$ e $<30$ (Over weight) & 16 & $50 \%$ \\
\hline$\geq 30$ (Obesity) & 5 & $15.7 \%$ \\
\hline \multicolumn{3}{|l|}{ Dominant Member } \\
\hline Right & 30 & $93.7 \%$ \\
\hline Left & 2 & $6.3 \%$ \\
\hline \multicolumn{3}{|l|}{ Trauma Variables } \\
\hline \multicolumn{3}{|l|}{ Type of trauma } \\
\hline Automobile accident & 4 & $12.5 \%$ \\
\hline Motorcycle accident & 12 & $37.5 \%$ \\
\hline Falls & 7 & $21.8 \%$ \\
\hline Sprain & 3 & $9.4 \%$ \\
\hline Playing ball & 3 & $9.4 \%$ \\
\hline Bump & 2 & $6.3 \%$ \\
\hline PFA & 1 & $3.1 \%$ \\
\hline
\end{tabular}

\begin{tabular}{|c|c|c|}
\hline Variable & Frequency & Percentage \\
\hline \multicolumn{3}{|l|}{ Trauma Variables } \\
\hline \multicolumn{3}{|l|}{ Type of lesion } \\
\hline Tibia and fibula & 8 & $25 \%$ \\
\hline Tibia & 7 & $21.9 \%$ \\
\hline Femur & 6 & $18.8 \%$ \\
\hline Ankle & 4 & $12.5 \%$ \\
\hline Lateral malleolus & 3 & $9.3 \%$ \\
\hline Bimalleolar & 2 & $6.3 \%$ \\
\hline Fibula & 1 & $3.1 \%$ \\
\hline Trimalleolar & 1 & $3.1 \%$ \\
\hline \multicolumn{3}{|l|}{ Variables of clinical care } \\
\hline \multicolumn{3}{|l|}{ Fractured limb } \\
\hline Right & 15 & $46.9 \%$ \\
\hline Left & 17 & $53.1 \%$ \\
\hline \multicolumn{3}{|l|}{ Injury time (years) } \\
\hline $0-1$ & 0 & $0 \%$ \\
\hline $1-2$ & 8 & $25 \%$ \\
\hline Over 3 years & 24 & $75 \%$ \\
\hline \multicolumn{3}{|l|}{ Length of hospital stay (days) } \\
\hline $0-4$ & 4 & $12.5 \%$ \\
\hline $5-10$ & 9 & $28.1 \%$ \\
\hline $11-20$ & 8 & $25 \%$ \\
\hline $20-80$ & 11 & $34.4 \%$ \\
\hline \multicolumn{3}{|l|}{ Intra-hospital physiotherapy } \\
\hline Yes & 14 & $43.7 \%$ \\
\hline No & 18 & $56.3 \%$ \\
\hline Extra-hospital Physiotherapy & 26 & \\
\hline Yes & 6 & $81.3 \%$ \\
\hline No & & $18.7 \%$ \\
\hline
\end{tabular}

Note: $\mathrm{BMI}=$ Body Mass Index; PFA = Projectiles by Firearm;

Regarding functional performance of the lower limb, Table 2 presents the results for WOMAC and LEFS. Table 3 shows the averages and standard deviations of the values of all the outcome measures.

Table 2 - Values of functional performance questionnaires

\begin{tabular}{|l|l|l|}
\hline Variable & Average (SD) & CI (95\%) \\
\hline WOMAC & $73(19)$ & $66-80$ \\
\hline LEFS & $3,1(14)$ & $-1.9-8.2$ \\
\hline
\end{tabular}

Note: WOMAC $=$ Western Ontario and MacMaster Universities Osteoarthritis Index; LEFS =

Lower Extremity Functional Scale; SD = Standard Deviation; $\mathrm{Cl}=$ Confidence Interval. 
As can be observed in Table 3, except for the peak of flexor torque, all outcome measures showed statistically significant differences between the limbs, with the affected limb presenting lower values in relation to the nonaffected limb. The differences between limbs with effect size classified as large were observed for muscle thickness (ES $=1.25$, mean deficit of $0.40 \mathrm{~mm}$ ) and for dorsiflexion amplitude $(\mathrm{ES}=0.91$, mean deficit of $3.4 \mathrm{~cm})$. In all other comparisons, effect sizes classified as moderate were obtained, including peak flexor torque, which did not demonstrate a statistically significant difference between limbs.

Table 3 - Results of the comparison between members for all outcome measures

\begin{tabular}{|c|c|c|c|c|c|c|c|}
\hline Variable & & Average (SD) & $\mathrm{Cl}(95 \%)$ & Deficit (SD) & $\mathrm{Cl}(95 \%)$ & Value of $p$ & ES \\
\hline $\begin{array}{l}\text { Ultrasound } \\
(\mathrm{mm})\end{array}$ & $\begin{array}{l}\text { AL } \\
\text { NAL }\end{array}$ & $\begin{array}{l}2.1(0.40) \\
2.6(0.40)\end{array}$ & $\begin{array}{l}2.0-2.3 \\
2.4-2.7\end{array}$ & $0.42(0.10)$ & $0.62-0.22$ & 0.0001 & 1.25 \\
\hline Isokinetic (N.m) & & & & & & & \\
\hline Extension $60^{\circ} / \mathrm{s}$ & $\begin{array}{l}\mathrm{AL} \\
\mathrm{NAL}\end{array}$ & $\begin{array}{l}137(57) \\
174(53)\end{array}$ & $\begin{array}{l}116-158 \\
155-193\end{array}$ & 37 (14) & $64-9.4$ & 0.0094 & 0.67 \\
\hline Flexion $60^{\circ} / \mathrm{s}$ & $\begin{array}{l}\mathrm{AL} \\
\mathrm{NAL}\end{array}$ & $\begin{array}{l}84(30) \\
98(30)\end{array}$ & $\begin{array}{l}73-95 \\
87-109\end{array}$ & $14(7.5)$ & $29-0.76$ & 0.0624 & 0.46 \\
\hline $\begin{array}{l}\text { Dorsiflexion of } \\
\text { ankle }(\mathrm{cm})\end{array}$ & $\begin{array}{l}\mathrm{AL} \\
\mathrm{NAL}\end{array}$ & $\begin{array}{l}3.1(3.4) \\
6.4(3.8)\end{array}$ & $\begin{array}{l}1.8-4.3 \\
5.1-7.8\end{array}$ & $3.4(0.90)$ & $5.2-1.6$ & 0.0004 & 0.91 \\
\hline $\begin{array}{l}\text { Simple jump } \\
(\mathrm{cm})\end{array}$ & $\begin{array}{l}\text { AL } \\
\text { NAL }\end{array}$ & $\begin{array}{l}76(43) \\
104(38)\end{array}$ & $\begin{array}{l}61-92 \\
90-117\end{array}$ & $27(10)$ & $48-6.9$ & 0.0094 & 0.69 \\
\hline $\begin{array}{l}\text { Triple jump } \\
\text { (cm) }\end{array}$ & $\begin{array}{l}\text { AL } \\
\text { NAL }\end{array}$ & $\begin{array}{l}221 \text { (127) } \\
298(106)\end{array}$ & $\begin{array}{l}175-267 \\
259-336\end{array}$ & $76(29)$ & $130-18$ & 0.0114 & 0.65 \\
\hline
\end{tabular}

\section{Discussion}

The results of this investigation demonstrated that, even in the late period, the study participants still present important structural, physical and functional deficits after unilateral fracture in the lower limbs submitted to surgical treatment. From the public health point of view, the results of the present study may serve as an alert because the rehabilitation process of these patients may not have achieved the necessary efficacy to recover important objective variables of the musculoskeletal system.

In the sample studied, $43.7 \%$ underwent in-hospital physiotherapy and $81.3 \%$ underwent extra-hospital physiotherapy. This study did not aim to determine the factors that negatively influenced the outcomes obtained in the affected limbs, considering that the adaptations occurred even with physiotherapy, it is hypothesized that the 
intervention process in these patients needs to be more judicious and resolutive. Although we know that other factors such as the affected bone, the severity of the trauma, the type of surgery, the type of osteosynthesis, the time of hospitalization, the time of immobilization and the time necessary to recover the total weight discharge in the affected limb may to influence the negative outcomes observed in this study.

Previous studies have shown that the effects of hospitalization for prolonged days, eight or more days, result in the loss of lean muscle mass and the decline in strength in these individuals and predispose to future hospitalization episodes $[24,54,55]$. In the present study, the results found for measures of muscle mass of the vastus lateralis were very significant and there is no other study in the literature that reports the same result for patients after fracture of lower limb with a minimum of one year of hospital discharge. In the study conducted by Gruther et al. [56] the loss of muscle mass of the quadriceps femoris muscle was evaluated in intensive care patients using ultrasound, in which it was concluded that during the first 2-3 weeks of immobilization in the therapy unit a considerable loss of limb muscle mass was lost.

In relation to the muscular strength deficit, the study by Hennrikus et al. $(p=0.006)$ showed that there was a persistent deficit in quadriceps femoral muscle strength of the fractured limb $(p=0.006)$, which was performed in participants younger than 17 years and with a mean of 33 months post femoral fracture $(\mathrm{n}=$ 33). Faergemann et al. [26] evaluated patients from 18 to 64 years old with unilateral lower limb fracture (n $=158$ ) to identify incapacity after 6 months of injury. Decreased muscle strength was observed between 17 and $25 \%$ in the affected limb. Leppalla et al. [27], when analyzing patients who suffered fractures of the lower limbs aged seven to 15 years, reported that there is a great loss of bone mass mainly in the first months after fracture. The authors report that the bone density of these patients is significantly lower in the affected limb compared to the non-affected limb $(p=0.011)$ even after more than two years of injury. It was also observed an association between loss of bone mass with loss of function $(\mathrm{p}=0.034)$ and muscle strength $(\mathrm{p}<0.001)$ in the same limb. Finally, it was demonstrated that the muscular strength of these patients is also significantly lower in the affected limb compared to the non-affected limb, after more than two years of injury.
Lin et al. [58] studied the limitation of short and medium-term activity, pain, mobility and range of motion of ankle dorsiflexion in people after ankle fracture $(n=150)$. Only the range of motion of ankle dorsiflexion and pain contributed independently to the clinical prediction rule $(\mathrm{p}<0.01)$. According to the study by Batista et al. [4] individuals who suffered traumatic lower limb fractures also presented reduced range of motion, static and dynamic imbalances in orthostatic posture and ambulation, which were significantly improved after a period of six months, and that even with improvement until the period of 24 months, was lower than that found in the initial period. In the study by Ceroni et al. [16], strength and power performance were assessed during a single leg vertical jump test using a force platform performed 18 months after fracture of the lower limb in 39 adolescents and similarly in healthy control subjects. A significant difference for maximal muscle power measurement was found $(p=0.0003)$ between the affected and non-affected leg.

This study had the following limitations: (I) although we obtained a listing with a considerable number of patients, many telephones could not be contacted because of numbers that did not exist or with out-ofarea service; (II) the absence of a control group, because we do not know to what extent the limb considered not affected could also present some consequent deficit of the contralateral lesion; (III) for logistical and operational reasons, it was not possible to evaluate more muscles of the lower limb, such as femoral and anterior tibial biceps; (IV) the lack of access to medical classification of fractures and the functional characteristics of patients at the time of hospital discharge did not allow us to correlate indirectly the outcomes with fracture profiles and high functional status.

\section{Conclusion}

In this study, statistically significant differences and size of the effect of the differences classified as moderate to large (muscle width of the vastus lateralis, knee extension force, ankle dorsiflexion amplitude, single horizontal jump and triple horizontal jump) were demonstrated among the measures of the affected versus non-affected limb in individuals who suffered a unilateral fracture of the surgically treated limb. 


\section{Acknowledgements}

We thank all undergraduate and scientific initiation students in physiotherapy who collaborated with the collections and the Coordination of Improvement of Higher Level Personnel (CAPES) allowed the student, through development, to perform their function with exclusive dedication.

\section{References}

1. Moreira BS. A Biomecânica da fratura e o processo de cicatrização. Cade. Unisuam. 2013;3(1):101-117.

2. Zago APV, Grasel CE, Padilha JA. Incidência de atendimentos fisioterapêuticos em vítimas de fraturas em um hospital universitário. Fisioter. Mov. 2009;22(4):565-573.

3. Lin MR, Kraus JF. A review of risk factors and patterns of motorcycle injuries. Accid Anal Prev. 2009;41(4):710-722.

4. Albuquerque ALM, Sousa Filho PGT, Braga Junior MB, Cavalcante Neto JS, Medeiros BBL, Lopes MBG. Epidemiology of fractures in patients from small towns in Ceará treated by the SUS. Acta Ortop. Bras. 2012;20(2):66-69.

5. Batista FS, Silveira LO, Castillo JJA, Pontes JE, Villalobos LDC. Epidemiological profile of extremity fractures in victims of motorcycle accidents. Acta Ortop Bras. 2015;23(1):43-6.

6. Peck C, Braverr E, Shen H, Kraus JR. Lower extremity injuries from motorcycle crashes: common cause of preventable injury. J Trauma Acute Care Surg. 1994;37(3):358-364.

7. Fernandez WG, Yard EE, Comstock RD. Epidemiology of lower extremity injuries among u.s. high school athletes academic emergency. Acad Emerg Med. 2007;14(7):641-645.

8. Arruda LRP, Silva MAC, Malerba FG, Turíbio FM, Fernandes MC, Matsumoto MH. Open Fractures: prospective and epidemiologic study. Acta Ortop Bras. 2009;17(6):326-30.

9. Murgatroyd DF, Harris IA, Tran Y, Cameron ID. Predictors of return to work following motor vehicle related orthopaedic trauma. BMC Musculoskelet Disord. 2016;7(1):171.
10. Pan RH, Chang NT, Chu D, Hsu KF, Hsu YN, Hsu JC, et al. Epidemiology of orthopedic fractures and other injuries among inpatients admitted due to traffic accidents: a 10-year nationwide survey in Taiwan. ScientificWorldJournal. 2014.

11. Court-Brown CM, Caesar B. Epidemiology of adult fractures: A review. Injury. 2006;37(8): 691-697.

12. Braga Júnior $M B$, Chagas Neto FA, Porto MA, Barroso TAB, Lima ACM, Silva SM, et al. Epidemiologia e grau de satisfação do paciente vítima de trauma músculoesquelético atendido em hospital de emergência da rede pública brasileira. Acta Ortop Bras. 2005;13(3):137-40.

13. Court-Brown CM, Caesar BC. The epidemiology of fractures. In: Bucholz RW, Heckman JD, Court-Brown CM. Rockwood \& Green's Fractures in adults. 6th ed. Philadephia: Lippincott Williams \& Wilkins; 2006:96-113.

14. Naumann RB, Dellinger AM, Zaloshnja E, Lawrence BA, Miller TR. Incidence and total lifetime costs of motor vehicle-related fatal and non-fatal injury by road user type in the United States, 2005. Traffic Inj Prev. 2010;11(4):353-360.

15. Fernandes FF, Saionara CCR, Camara MA, Maciel ACC. Fatores associados ao não retorno ao trabalho deindivíduos acidentados de moto: um estudo epidemiológico. Rev. Baiana de Saúde Pública. 2015;39(2):191.

16. Labronici PJ, Reis FB, Fernandes HJ. Estudo prospectivo do uso da haste intramedular bloqueada não fresada em fraturas fechadas e expostas da diáfise da tíbia. Rev. Bras. Ortop. 2006;41(9):373-383.

17. Ceroni D, Martin XE, Farpour-Lambert NJ, Delhumeau C, Kaelin A. Assessment of muscular performance in teenagers after a lower extremity fracture. J Pediatr Orthop. 2010;30(8):807-812.

18. Keene DJ, Williamson E, Bruce J, Willett K, Lamb SE. Early Ankle Movement Versus Immobilization in the Postoperative Management of Ankle Fracture in Adults: A Systematic Review and Meta-analysis. September 2014; volume 44; number 9; Journal of Orthopaedic \& Sports Physical Therapy.

19. Van Son MA, De Vries J, Roukema JA, Gosens T, Verhofstad $\mathrm{MH}$, Den Oudsten BL. The course of health status and (health-related) quality of life following fracture of the lower extremity: a 6-month follow-up study. Qual Life Res. 2016; 25(5):1285-1294. 
20. Sousa KM, Oliveira WIF, Alves EA, Gama ZAS. Fatores associados ao acesso à reabilitação física para vítimas de acidentes de trânsito. Rev Saude Publica. 2017;51:1-13.

21. Sanders DW, MacLeod M, Charyk-Stewart T, Lydestad J, Domonkos A, Tieszer C. Functional outcome and persistent disability after isolated fracture of the femur. Can J Surg. 2008;51(5):366.

22. Son MAC, Vries J, Roukema JA, Gosens T, Verhofstad MHJ, Oudsten BL. The course of health status and (healthrelated) quality of life following fracture of the lower extremity: a 6-month follow-up study. Qual Life Res. 2016;25(5):1285-1294.

23. Stevens JE, Walter GA, Okereke E, Scarborough MT, Esterhai JL, George SZ, et al. Muscle Adaptations with Immobilization and Rehabilitation after Ankle Fracture. Med. Sci. Sports Exerc. 2004;36(10):1695-1701.

24. Portegijs E, Rantanen T, Kallinen M, Heinonen A, Alen M, Kiviranta I, et al. Lower-limb pain, disease, and injury burden as determinants of muscle strength deficit after hip fracture. J Bone Joint Surg Am. 2009;91(7):1720-1728.

25. Franck H, Scherrer MM. Evaluation of Dual-Energy X-Ray Absorptiometry Bone Mineral Measurement Comparison of a Single-Beam and Fan-Beam Design: The Effect of Osteophytic Calcification on Spine Bone Mineral Density. Calcif Tissue Int. 1995;56(3):192-195.

26. Faergemann C, Frandsen P, Rock N. Residual impairment after lower extremity fracture. J Trauma.1998;45(1):123-126.

27. LeppäläJ, KannusP, Sievänen H,Vuori I,Järvinen M. Atibial shaft fracture sustained in childhood or adolescence does not seem to interfere with attainment of peak bone density. J. Bone Miner. Res. 1999;14(6):988-993.

28. Gandek B. Measurement properties of the Western Ontario and McMasterUniversities Osteoarthritis Index: a systematic review. Arthritis Care Res (Hoboken). 2015 Feb;67(2):216-29. doi: 10.1002/acr.22415.

29. Ebrahimzadeh MH, Makhmalbaf H, Birjandinejad A, Keshtan FG, Hoseini HA, Mazloumi SM. The Western Ontario and McMaster Universities Osteoarthritis Index (WOMAC) in Persian Speaking Patients with Knee Osteoarthritis. Arch Bone Joint Surg. 2014;2(1):57-62.
30. Martín-Fernández J, Gray-Laymón P, Molina-Siguero A, Martínez-Martín J, García-Maroto R, García-Sánchez I, et al. Cross-cultural adaptation and validation of the Spanish version of the Oxford Hip Score in patients with hip osteoarthritis. BMC Musculoskelet Disord. 2017;18(1):205, 2017.

31. Metsavaht L, Leporace G, Riberto M, Sposito MM, Del Castillo LN, Oliveira LP, et al. Translation and Crosscultural Adaptation of the Lower Extremity Functional Scale Into a Brazilian Portuguese Version and Validation on Patients With Knee Injuries. J Orthop Sports Phys Ther. 2012;42(11):932-939.

32. Gomes PSC, Meirelles CM, Leite SP, Montenegro CAB. Reliability of Muscle Thickness Measurements Using Ultrasound. Rev Bras Med Esporte. 2010;16(1):41-45.

33. Noorkoiv M, Nosaka K, Blazevich AJ. Assessment of quadriceps muscle cross-sectional area by ultrasound extended-field-of-view imaging. Eur. J. Appl. Physiol. 2010;109(4):631-639.

34. Blazevich AJ, Coleman DR, Horne S, Cannavan D. Anatomical predictors of maximum isometric and concentric knee extensor moment. Eur. J. Appl. Physiol. 2009;105(6):869-878.

35. Nijholt W, Scafoglieri A, Jager-Wittenaar H, Hobbelen JSM, van der Schans CP. The reliability and validity of ultrasound to quantify muscles in older adults: a systematic review. J Cachexia Sarcopenia Muscle. 2017;8:702-712.

36. Lima KMM, Oliveira L F. Confiabilidade das medidas de arquitetura do músculo Vasto Lateral pela ultrassonografia. Motriz: Rev. Edu. Fisica. 2013;19(1):217-223.

37. Drouin JM, Valovich TC, Shultz SJ, Gansneder BM, Perrin DH. Reliability and validity of the Biodex System 3 Pro Isokinetic Dynamometer velocity, torque and position measurements. Eur. J. Appl. Physiol. 2004;91(1):22-29.

38. Caruso JF, Brown LE, Tufano JJ. The reproducibility of isokinetic dynamometry data. Isokinet Exerc Sci. 2012;20(4):239-253.

39. Deighan MA, De Ste Croix MBA, Armstrong N. Reliability of isokinetic concentric and eccentric knee and elbow extension and flexion in 9/10 year old boys. Isokinet Exerc Sci. 2003;11(2):109-115. 
40. Bennel K, Richard T, Henry W, Wassana T, David K. Intrarater and inter-rater reliability of a weight-bearing lunge measure of ankle dorsiflexion. Aust J Physiother. 1998;44(3):175-180.

41. Venturini C, Ituassú NT, Teixeira LM, Deus CVO. Intrarater and interrater reliability of two methods for measuring the active range of motion for ankle dorsiflexion in healthy subjects Rev. Bras. fisioter. 2006;10(4):407-411.

42. Hamilton RT, Shultz SJ, Schmitz RJ, Perrin DH. Triple-Hop Distance as a Valid Predictor of Lower Limb Strength and Power. J Athl Train. 2008;43(2):144-151.

43. Moussa AZB, Zouita S, Dziri C, Ben Salah FZ. Singleleg assessment of postural stability and knee functional outcome two years after anterior cruciate ligament reconstruction. Ann Phys Rehabil Med. 2009;52(6):475-484.

44. Bolgla LA, Keskula DR. Reliability of Lower Extremity Functional Performance Tests. J Orthop Sports Phys Ther.1997;26(3):138-142.

45. Selistre LFA, Cintra GC, Aleixo Junior RD, Rosa SMMG. Relationship Between Extensor tor que and H: Q Ratio With Triple Hop Distance in Professional Soccer Players. Rev Bras Med Esporte. 2012;18(6):390-393.

46. Kawakami Y, Abe T, Kanehisa H, Fukunaga T. Human Skeletal Muscle Size and Architecture: Variability and Interdependence. Am. J. Hum. Biol. 2006;18(6):845-848.

47. Blazevich AJ, Cannavan D, Coleman D, Horne S. Influence of concentric and eccentric resistance training on architectural adaptation in human quadriceps muscles. J. Appl. Physiol. 2007;103(5):1565-1575.

48. Blazevich AJ, Coleman DR, Horne S, Cannavan D. Anatomical predictors of maximum isometric and concentric knee extensor moment. Eur J Appl Physiol; 2009;105(6):869-878.b

49. Abe T, Kumagai K, Brechue WF. Fascicle length of leg muscles is greater in sprinters than distance runners. Med Sci Sports Exerc. 2000;32(6):1125-1129.

50. Reeves N, Maganaris C, Longo S, Narici MV. Differential adaptations to eccentric versus conventional resistance training in older humans. Exp Physiol. 2009;94(7):825-833.
51. Kollock R, Van Lunen BL, Ringleb SI, Oñate JA. Measures of functional performance and their association with hip and thigh strength. J Athl Train. 2015;50(1):14-22.

52. Thalheimer W, Cook S. How to calculate effect sizes from published research: A simplified methodology. WorkLearning Research. 2002:1-9.

53. Lustosa LP, Fonseca ST, Andrade MAP. Reconstruction of the anterior cruciate ligament: impact of muscular and functional performances at the return to pre-injury activity level. Acta Ortop Bras. 2007;15(5):280-284.

54. Alley DE, Koster A, Mackey D, Cawthon P, Ferrucci L, Simonsick EM, et al. Hospitalization and Change in Body Composition and Strength in a PopulationBased Cohort of Older Persons. J Am Geriatr Soc. 2010;58(11):2085-2091.

55. Visser M, Harris TB, Fox KM, Hawkes W, Hebel JR, Yahiro JY, et al. Change in muscle mass and muscle strength after a hip fracture: relationship to mobility recovery.J Gerontol A Biol Sci Med Sci. 2000;55(8):434-440.

56. Gruther W, Benesch T, Zorn C, Paternostro-Sluga T, Quittan M, Fialka-Moser V, et al. Muscle wasting in intensive care patients: ultrasound observation of the M. quadriceps femoris muscle layer. J Rehabil Med. 2008;40(3):185-189.

57. Hennrikus WL, Kasser JR, Rand F, Millis MB, Richards KM. The function of the quadriceps muscle after a fracture of the femur in patients who are less than seventeen years old. J Bone Joint Surg Am. 1993;75(4):508-513.

58. Lin CW, Moseley AM, Herbert RD, Refshauge KM. Pain and dorsiflexion range of motion predict short- and medium-term activity limitation in people receiving physiotherapy intervention after ankle fracture: an observational study. Aust J Physiother. 2009;55(1):31-37.

Received in 08/11/2017 Recebido em 11/08/2017 Recibido en 08/11/2017

Approved in 28/08/2018 Aprovado em 08/28/2018 Aprobado en 28/08/2018 